\title{
Does Adoption of International Financial Reporting Standards (IFRS) Affect Financial Performance? Evidence from Nigerian Deposit Money Banks
}

\author{
Meshack Aggreh \\ Accounting Department, Veritas University, Abuja, Nigeria \\ E-mail: aggrehmeshack@gmail.com \\ Charles A. Malgwi (Correspondence Author) \\ Accountancy Department, Bentley University \\ 175 Forest Street, Waltham, MA, 02452, USA \\ Tel: +1-781-891-2774Ｅ-mail: cmalgwi@bentley.edu \\ Amanda E. Enyi-Igbokwe \\ Blackbit Limited, Investment Banking, Abuja, Nigeria \\ E-mail: amandaigbokwe@gmail.com \\ Mercy S. Aggreh \\ Accounting Department, Veritas University, Abuja, Nigeria \\ E-mail: aggrehmercy@gmail.com
}

Received: June 23, 2018

doi:10.5296/ijafr.v8i3.13309
Accepted: July 29, 2018

Published: August 5, 2018

URL: https://doi.org/10.5296/ijafr.v8i3.13309

\begin{abstract}
This paper examines the effect of International Financial Reporting Standards (IFRS) adoption on financial performance of eleven (11) deposit money banks listed on the Nigerian Stock Exchange (NSE) as at December 31, 2014. The Wilcoxon Signed-Rank test was used to test whether significant differences exist in the profitability, liquidity and leverage ratios of
\end{abstract}


the selected banks using IFRS and Nigerian Statement of Accounting Standards (SAS) based financial statements. The results show that adoption of IFRS does significantly affect financial performance of Nigerian deposit money banks. Specifically, IFRS adoption significantly and positively affects profitability of Nigerian deposit money banks, while it significantly, but negatively affects their liquidity and financial leverage. The study recommends continuous enlightenment campaigns on the potential effects of IFRS implementation by the regulatory authorities, professional bodies and the government as more and more firms in Nigeria change from SAS based financial reporting to IFRS. Furthermore, firms should endeavour to use the opportunity presented by the IFRS to improve their business processes in all ramifications so as to promote uniformity and transparency.

Keywords: Harmonization, Convergence, IFRS adoption, Agency theory, Stakeholder theory, Stewardship theory, Financial performance, Deposit money banks, Nigeria

\section{Introduction}

International Financial Reporting Standards (IFRS) are accounting standards developed by the International Accounting Standards Board (IASB) has become the global platform for the preparation and presentation of public companies' financial statements. IFRS is established for business dealings to enhance understanding and comparability across international boundaries. Accounting is the language of business and businesses around the world can no longer afford to be speaking in different languages with each other while sharing and exchanging results of their international business activities (Holt and Mirza, 2011). The framework for the preparation and presentation of financial statements depicts the principles underlying IFRS. The IASB's IFRS Framework states that; "The objective of financial statements is to provide information about the financial position, performance and changes in financial position of an entity, that is useful to a wide range of users in making economic decisions" (IASB, 2010).

The attestation towards the adoption of IFRS is the expectation to create either in the long run or short run, an increase in shareholder's wealth. In the light of this attestation, the benefits attributed to the adoption of IFRS are innumerable and are continuously questioned by several accounting professionals. Most studies on IFRS looked at it strictly as a financial reporting issue. But financial reporting is one aspect of the total impact of IFRS on corporations. The adoption of IFRS arguably leads to more accurate, comprehensive and timely financial reports better comparability of financial statements and much more, transparency in reporting (Daske and Gebhardt, 2006; Ball, 2006; Barth, Jagolizer, Armstrong and Riedl, 2008; Chua and Taylor, 2008; Gebhardt and Novotny-Farkas, 2010). The Implementation of IFRS reduces information irregularity and strengthens the communication link between all stakeholders (Bushman and Smith, 2001). It also reduces the cost of preparing different versions of financial statements where an organization is a multi-national (Healy and Palepu, 2001).

The need for harmonization of financial statements and single set of consistent high quality financial reporting standards gained wide spread acceptance amongst policy makers and 
preparers of financial statements due to the increase in the volume of cross border capital flows and the growing number of foreign direct investments. Before the global convergence to IFRS, different countries of the world had their respective accounting standards, developed, issued and regulated by their respective local standards board. This made comparison of results of companies operating in different financial reporting jurisdictions rather difficult.

The transition to a global uniform framework is, therefore, an eloquent authentication of the international consensus on IFRS as the benchmark for assessment of the financial health of economic entities across the globe (Herbert and Tsegba, 2013). The change from local standards to IFRS causes a change in the accounting representation of the firm's financial position and performance that may cause investors to revalue the equity of the firm (Wang and Welker, 2010). The likely changes in accounting representation of the financial performance of firms remain a subject for continued empirical debate. The contending issue is whether such changes have the potential to present a more attractive position of the financial performance of the firms or otherwise.

The discontentment derived from globalisation is as a result of the increasing disparity between the developed western countries and developing countries. IFRS is a product of many generations of international harmonization discourse. Prior to the adoption of IFRS in Nigeria, Statement of Accounting Standards (SAS) was used in preparing and reporting financial information. Notwithstanding that the theoretical basis and general principles in SAS correspond with IFRS in certain areas, innumerable differences exist. There have been arguments among researchers and accounting professionals that the adoption of IFRS can be disturbing to some countries if financial statement figures are negatively altered by IFRS adoption thereby putting those countries' companies in a competitive disadvantage in the global market. It is widely believed that the lack of proper use of international accounting standards in affected countries of which Nigeria is a part, hinders transparency and comparison in the financial statements of companies (Luqman, 2014). As a result of this, financial statements fail to provide useful and accurate information that will be used for good investment decisions on a timely basis.

This study is a response to the paramount need of users of financial statements to know the impact on financial performance as a result of the change to IFRS. However, there is paucity of research works in this area of study in Nigeria and to some extent in the developing countries. Furthermore, the few studies that were conducted showed mixed results due mainly to inappropriate data analysis technique. Using some ratios selected from three major categories of financial ratios and a sophisticated analytical tool, the study seeks to examine the effect of IFRS adoption on the financial performance of selected deposit money banks in Nigeria and thus intends to mitigate the above limitations of previous studies. This study therefore seeks to provide answers to the question, whether the financial performance of Nigerian banks compiled under SAS differs significantly from that compiled using IFRS. It is expected that the research findings will be beneficial to banks, shareholders, would-be investors, academics and the general reading public.

The main objective of this study, therefore, is to examine the effect of IFRS adoption on 
financial performance of selected deposit money banks in Nigeria. To achieve this main objective, specific objectives are outlined:

a) To ascertain whether significant differences exist in the profitability of selected deposit money banks using IFRS and SAS.

b) To ascertain whether significant differences exist in the liquidity of selected deposit money banks using IFRS and SAS.

c) To ascertain whether significant differences exist in the financial leverage of selected deposit money banks using IFRS and SAS.

The hypotheses of the study in its null form are as stated below:

$\mathbf{H}_{1}$ : IFRS adoption does not significantly affect profitability of Nigerian banks.

$\mathbf{H}_{2}$ : IFRS adoption does not significantly affect liquidity of Nigerian banks.

$\mathbf{H}_{3}$ : IFRS adoption does not significantly affect financial leverage of Nigerian banks.

The rest of the paper is organised as follows: section two reviews extant literature relevant to the study, section three discusses the research methodology applied, section four presents the type and nature of the data used in the study, while section five presents and discusses the results of the study. The last section summarizes the findings, conclusion and recommendations.

\section{Literature Review}

The international convergence of accounting standards is no longer a new concept. According to Nobes (2006), the notion first came to light in the late 1950s in response to post World War II economic integration and related increases in cross-border capital flows. The charge to promote a collective set of accounting standards emanated from international differences downsized by investment opportunities (IFAC, 2008).

The merging of the diverse accounting standards and the evolutionary changes that resulted in the development of IFRS however, are contemporary issues in the world of accounting. At first, a lot of efforts centred on harmonization which brought about reducing differences among the accounting principles used in major capital markets around the world. The notion of harmonization was reinstated by the concept of convergence; the development of a single set of high quality, international accounting standards that would be used in at least all major capital markets in the 1990s. However, Herbert (2010) ascertained that various attempts have been made and are still on-going to eliminate or reduce many of the major differences in accounting standards through a process known as harmonization. As a result of the inherent diversity during the era, internationalization of accounting standards was presumed as an endeavour of conflicts (Choi and Mueller, 1984). These conflicts are entrenched in the process of standard setting which is publicly instigated in some countries and, in others, through the recognized professional accountancy bodies. These societal alterations in the manner of standard setting inevitably gave rise to the vogue of diverse standards in different countries. 


\subsection{Financial Reporting in Nigeria}

The Nigerian Accounting Standard Board (NASB), at its amalgamation as a board gave the introductory collective and professional mind-set with regards to the regulation of the accountancy profession in Nigeria in 1982. As an arm of a government parastatal, NASB issued some standards which though, were not wholeheartedly followed by all players, served effectively in providing a uniform basis for locally based companies and preparers of financial statements (ICAN, 2006). The major setback of the NASB was the refusal of multinational companies to adopt the SASs as they considered it mere codifications of the extant International Accounting Standards (Nigeria’s Financial Hub, 2011).

The continual public outcry as well as the urgent need to adopt IFRS therefore, necessitated the need for the enactment of the Financial Reporting Council of Nigeria (FRCN) in 2011. In June 2011, legislative changes were enacted under which the FRCN replaced the NASB as the entity responsible to aid the implementation of IFRS in Nigeria.

The FRCN is now the body corporate solely responsible for the issuance, monitoring and review of Accounting and Auditing Standards in Nigeria. The council is empowered under section 52(1) of the Act to adopt and keep up-to-date accounting and auditing standards, and to ensure consistency between Standards issued under IFRS as provided under Part VII of FRCN Act 2011, which dealt with review and monitoring of standards. This is one of the major developments brought by the FRCN Act in 2011, where the Federal Executive Council approved the adoption of IFRS as the reporting framework to publicly quoted entities by 2012 in Nigeria. However, as observed by Obazee (2012), the "FRCN will require management assessment of internal controls, including Information Systems Controls with independent attestation". Also, as part of the FRCN oversight of professionals, "the FRCN requires good code of ethics for financial officers and certification of financial statements by chief executive officers and chief financial officers" of reporting entities (Obazee, 2012). Moresa, the FRCN will reinvigorate efforts in restoring public confidence in financial reporting as it "issues code of corporate governance and guidelines and develop a mechanism for periodic assessment of the codes and the guidelines" (Obazee, 2012). Furthermore, lending support to the enactment of the FRCN act, Anao (2012) argues that the development is timely as it expands the scope of financial regulation beyond traditional spheres of accounting and financial reporting and also spans auditing and corporate governance. The increased involvement of government in financial reporting presents a picture that is ardently passionate about the public interest.

Although regulatory framework of FRCN is potentially strong to support the on-going mandatory adoption of IFRS, Oduware (2012) argued that, some still consider IFRS to be an accounting function and its implementation lies within the finance function of companies. However, IFRS is rather more than accounting or finance; it is all-encompassing. It deals with the way and manner in which an entity conducts its business after giving consideration to its accounting and financial reporting implications. This is consistent with the view of Obazee (2012) who opined that, conversion to IFRS is more than an accounting exercise and will have an effect outside the finance function in areas such as: information technology, 
human resources; and investor relations. It also has a regulatory implication which is not limited to capital adequacy for banks, and solvency margins for insurance companies but it also affects capital management for all entities.

\subsection{Harmonization, Convergence, Adaptation and Adoption of IFRS}

Regardless of IFRS becoming the need of the hour around the world and companies aggressively attempting to globalize their operations, some perplexity still prevails over the difference between harmonization, adoption and convergence with IFRS. However, even in common dictions and contemporary literature, the terms are applied conversely amongst users of IFRS and it is important that in any IFRS discourse, the distinction be clarified.

The term harmonization clearly means "the reconciliation of different accounting and financial reporting systems by fitting them into common broad classifications, so that form becomes standard while content retains significant differences" (Odia and Ogiedu, 2013). Quigley (2007) believes that accounting harmonization is necessary for the globalization of capital markets. Convergence means to achieve harmony with IFRS; in precise terms, convergence with IFRS means that the country's accounting standards board (e.g. FRCN) in applying IFRS should work in accordance with IASB to develop high quality compatible accounting standards over time. Convergence is the process by which standard setters across the globe discuss accounting issues drawing on their combined experiences in order to arrive at the most appropriate solution. It is actually a gradual process of changing a country's accounting rules towards IFRS.

The ultimate objective of convergence is to achieve a single set of internally consistent, high global accounting standards, issued by the IASB and adopted by all the national standard setters (IASB, 2003). Obazee (2007) suggests that convergence could be either by adoption (a complete replacement of national accounting standards with IASB's standards) or by adaptation (modification of IASB's standards to suit peculiarities of local market and economy without compromising the accounting standards and disclosure requirements of the IASB's standards and basis of conclusions).

Another term that raises confusion in the IFRS lexicon is "adaptation". In simple terms, adaptation is referred to as any transition to IFRS that entails the modification of IASB's standards to suit national/jurisdictional peculiarities of interests even without compromising the accounting standards and disclosure requirements (Odia and Ogiedu, 2013).

On the other hand, "adoption" presupposes that national rules are set aside and replaced by IFRS requirement. To a layman, it can be understood that when a country adopts IFRS, it means that the country will be implementing IFRS in the same manner as issued by the IASB and shall be 100\% complaint with the guidelines issued by IASB (Odia and Ogiedu, 2013).

\subsection{Theoretical Framework}

This study is based on the agency theory, the stakeholder theory and the stewardship theory.

Therefore, this subsection reviews the agency theory, the stakeholder theory and the stewardship theory and how IFRS adoption connects with them. 


\subsection{Agency Theory}

Agency theory refers to a set of propositions in governing a modern corporation which is typically characterized by large number of shareholders or owners who allow separate individuals to control and direct the use of their collective capital for future gains. These individuals may not always own shares but may possess relevant professional skills in managing the corporation. The theory offers many useful ways to examine the relationship between owners and managers and verify how the final objective of maximizing the returns to the owners is achieved, particularly as the managers do not own the corporation's resources.

The agency theory has its roots in economic theory. This was exposited by Alchian and Demsetz (1972) and further developed by Jensen and Meckling (1976). In the agency theory, the principal (shareholders and owners) delegate the decision-making power to the agent (directors, managers and management) who may pursue interests that may not necessarily be in favour of the principal but may in fact hurt the principal through information asymmetry (Ross, 1973; Fama, 1980). The agency theory deals with entrusting resources to the agent who in turn is required to produce a report in qualitative and quantitative manner and are expected to align the interest of the owners of a business and managers in order for the set objectives of the organization to be achieved. The IFRS attempts to ensure full disclosure of relevant and material details arising in the course of economic events as well as transparency in the reporting channels. Hence, the adoption of IFRS will improve the owners-agent relationship thereby curbing any form of sub-optimality within a business concern.

\subsection{Stakeholder's Theory}

The term "stakeholders" refers to groups or constituents who have a legitimate claim on the firm (Freeman, 1984; Pearce, 1982). This legitimacy is established through the existence of an exchange relationship. Stakeholders include stockholders, creditors, managers, employees, customers, suppliers, local communities and the general public. According to March and Simon (1958), each of these groups can be seen as supplying the firm with critical resources (contributions) and in exchange each expects its interests to be satisfied (by inducements).

In 1963, the Stanford Research Institute (SRI) defined stakeholder's theory as those groups without whose support the organisation would cease to exist. Freeman (2004) modified the definition as those groups who are vital to the survival and success of the organisation. The stakeholder's theory focuses on the issues concerning the stakeholders in a firm. It stipulates that a corporate entity invariably seeks to provide a balance between the interests of its diverse stakeholders in order to ensure that each interest constituency receives some degree of satisfaction (Abrams, 1951). According to Gray, Owen and Adams (1996), practising stakeholder theory helps organisation to achieve the organisational goals which include increasing profitability. Craig (2010) asserted that the view of stakeholder theory is that all the stakeholders have right to be provided with information about how the organisation is affecting them (through community sponsorship, provision of employment, safety initiatives, etc.), even if they choose not to use the information and even if they cannot directly affect the survival of the organisation. Ullmann (1985) argues that the greater the importance to the 
organisation of the stakeholder's resources/ support, the greater the probability that a particular stakeholder's expectations will be accommodated within the organisation's operations. Moreover, organisations will have an incentive to disclose information about their various programs and initiatives to the stakeholder groups concerned to clearly indicate that they are conforming on those stakeholders' expectations, as organisations must necessarily balance the expectations of various stakeholder groups.

\subsection{Stewardship Theory}

Stewardship theory presents a different model of management, where managers are considered good stewards who will act in the best interest of the owners (Donaldson and Davis, 1991). Stewards are motivated only by making the right decisions which are in the best interest of the organisation, as there is strong assumption that stewards will benefit, if the firm is prospered. A steward protects and maximises shareholders wealth through firm performance, because by doing so, the steward's utility functions are maximized (Davis, Schoorman and Donaldson, 1997).

Stewardship is defined as the behaviour that places the long-term interest of the organisation as well as the shareholders ahead of individuals' self-interest (Caldwell and Karri, 2005). Stewardship theory sees a strong relationship between managers and the success of the firm. Donaldson and Davis (1989) argued that stewardship theory ignores individualism, rather firm executives and managers play their role as stewards by aligning their interest along with the organisation's goals.

\subsection{Review of Prior Studies}

Zeff (1978) first discussed the impact of financial reporting as economic consequences where he studied the impact of accounting reports on the decision-making behaviour of businesses, governments, unions, investors and creditors. There are three types of effects in the area of economic consequences in accounting and finance literature: the financial reporting effects, capital-market effects and macroeconomic effects (Bruggemann, Hitz and Sellhorn, 2013). A financial reporting effect is the concern of this study and reflects the immediate impact of the change in standards on properties of financial statements. The impact of IFRS adoption on key financial ratios is likely to be limited if a firm's institutional environment and the firm-level incentives remain unchanged. In the context of using ratio for examining the effects of IFRS adoption on various variables, a number of studies have been carried out.

Zayyad, Ahmad, and Mubaraq (2014) conducted a study to examine the effect of IFRS adoption on the performance evaluation of a particular firm using some ratios selected from four major categories of financial ratios. The study was conducted through comparison of the ratios that were computed from IFRS based financial statements and Nigerian SAS based financial statements. The study used the case study research approach and the population of the study was made up of Nigerian firms that were in compliance with IFRS in the year 2013. Oando Plc was the sample used and the years observed was from 2004-2010. The Mann-Whitney U test statistics was employed to test whether a significant difference exists between the ratios calculated from the pair of financial statements. The result of the 


\section{Mll Macrothink}

International Journal of Accounting and Financial Reporting

ISSN 2162-3082

2018, Vol. 8, No. 3

Mann-Whitney $U$ test showed that there is no significant difference between the pair of ratios. The findings showed that the disclosure of IFRS compliant set of financial statements do not contribute to higher financial performance using ratios of the case firm.

Ibiamke and Ateboh-Briggs (2014) conducted a study to examine the impact of IFRS adoption by Nigerian listed firms on key financial ratios used by investors. The study employed an innovative design known as "same firm-year" research design to examine how IFRS adoption changes key financial ratios of Nigerian listed firms. The population for the study comprised of 198 firms listed on the Nigerian Stock Exchange as at $31^{\text {st }}$ December 2010. A sample of 60 companies using a filter scale was used. Gray Index was used to find the impact of IFRS adoption on financial ratios while, Paired sample $t$ test and Levene's F test were used to test the statistical significance of the differences in mean and variances between ratios under IFRS and SAS respectively. The results show a negative impact on the financial ratios of Nigerian listed firms, but the impact was not statically significant. The study recommends that analysts and other financial statement users should be mindful of the new features of financial statement when taking economic decisions during this period of transition to IFRS in Nigeria.

Blanchette, Racicot and Girard (2011) provided a preliminary evidence of the impact on financial ratios caused by the transition to IFRS in Canada. The study compared 26 ratios computed from IFRS financial statements and Canada GAAP financial statements. Nine firms were used and the data were extracted from the financial statements prepared under each accounting standard during the transition years. Their results show that "IFRS's impact on financial ratios is driven by fundamental differences in application of fair value accounting and consolidation under IFRS and pre-changeover Canadian GAAP", they concluded that differences between IFRS and pre-changeover Canadian GAAP do not affect cash flows and most of the financial ratios under IFRS present a significantly higher volatility than those computed under pre-changeover Canadian GAAP”. Lantto and Sahlstrom (2009) conducted a study on the impact of IFRS adoption on key financial ratios of Finnish listed firms. This was achieved by calculating ratios from sampled 91 firms on the Helsinki Stock Exchange. The results show that the adoption of IFRS changes the magnitude of the key accounting ratios of Finnish companies; profitability ratios increased by $9.19 \%$ and the price-to-earning (PE) ratios decreased by $11 \%$, gearing ratios increased by $2.9 \%$ while equity ratios decreased by $0.2 \%$.

Punda (2011) based on Lantto and Sahlstrom (2009) examined the effects of IFRS adoption on key financial ratios of UK listed firms. The study used Non-parametric Wilcoxon Signed-Rank Test to test the statistical significance of the differences between the UK-GAAP based ratios and IFRS ratios. The data for the study was collected from the reconciliation reports, which were included in the company's annual reports of the year of transition. To assess full impact of IFRS adoption on UK-listed companies, the following financial ratios were used: operating profit margin (OPM), return on equity (ROE), return on invested capital (ROIC) current ratio (CR); and one market-based ratio. A sample of 250 firms listed on the FTSE was examined with only firms reporting all the information needed included. The study reported a substantial change in the key performance indicators of these firms due to the 
IFRS adoption.

In the light of the above studies, this study compares the financial ratios of a firm computed from its IFRS compliant financial statements and the Nigerian SAS based financial statements. The essence is to ascertain whether a significant difference between each pairs of ratios and whether such difference, if any, is better for the company by increasing stakeholders' assessment of the company's performance thus increasing its value.

\section{Research Methodology}

\subsection{Population of the Study}

The population for this study was all the twenty-one (21) banks quoted on the official daily lists of the Nigerian Stock Exchange (NSE) market making up the Nigerian banking sector as at December 31, 2011. For the purpose of this study, the Nigerian banks were stratified on the basis of those that adopted and reported their financial statements using IFRS and SAS.

\subsection{Sample Size and Sampling Technique}

Though there are different firms preparing and presenting their financial statements using SAS and IFRS, this study focuses on banks. However, due to the challenges of accessing the entire population, a sample was selected for the study using the judgemental sampling technique. A sample size of 11 banks were selected namely; Diamond Bank Plc, Ecobank Plc, Fidelity Bank Plc, First Bank of Nigeria (FBN) Plc, First City Monument Bank (FCMB) Plc, Skyebank Plc, Stanbic IBTC Bank, Standard Chartered Bank (SCB) Ltd, United Bank for Africa (UBA) Plc, Unity Bank of Nigeria Plc, and Wema Bank Plc based on availability of data necessary for the investigation.

\subsection{Source of Data}

This analysis is based on secondary data culled from several sources such as the annual reports of the selected banks, the daily stock listings reported in the National dailies, previous works and publications. This approach is relatively efficient and has readily available data for the analysis, which is to a reasonable extent, true and fair.

\subsection{Instruments of Data Collection}

The data for this study was majorly gotten from secondary sources. Two sets of financial statements for all observations were gathered; the first is IFRS financial statements and the other is SAS based financial statements for the same year (2011). Information on the adjustments made to the "pre-IFRS" year figures are extracted from the IFRS/SAS reconciliations. Although the reconciliations varied considerably in format and level of details supplied, the main aim was to separate which financial statement elements were impacted by IFRS and the amounts involved. To analyse our samples, three financial ratio categories were used; profitability, liquidity and financial leverage. The ratios were calculated based on figures obtained from financial statements that are constituted according to the two sets of accounting standards (SAS and IFRS) for the same year (2011).

\subsection{Definition and Measurement of Variables}




\section{Mll Macrothink}

International Journal of Accounting and Financial Reporting

ISSN 2162-3082

2018, Vol. 8, No. 3

The variables used in this study represent the measures of firm performance that may be affected by the adoption of IFRS. To measure financial performance (independent variable), three financial ratio categories were adopted; profitability ratio (Return on asset, ROA), Liquidity ratios (Current ratio), Financial leverage ratios (Debt to equity ratio, D/ER). These financial performance measures are useful to both external stakeholders (existing or potential investors, loan providers and suppliers) and internal stakeholders (corporate managers) to flag problems requiring financial reporting (Higgins, 2009).

ROA measures the net income produced by total assets during a period by comparing net income to the total assets. This ratio measures how efficiently a company can manage its assets to produce profits during the year. This ratio is calculated by dividing net profit after tax by total assets.

Current ratio is the balance sheet financial performance measure of company liquidity. It indicates a firm's ability to meet short term debt obligations with its short-term assets. This ratio is calculated by dividing current assets by current liabilities.

D/ER is a financial ratio indicating the relative proportion of entity's equity and debt used to finance an entity's assets. It is used as a standard for judging a company's financial standing and it is a measure of financial stability. It is calculated by dividing total liabilities by total equity. The variables and their measurements are shown below.

Table 1. Measurement of variables

\begin{tabular}{llcl} 
VARIABLES & DEFINITION & MEASUREMENT & SOURCE \\
$\boldsymbol{C} \boldsymbol{U} \boldsymbol{R}$ & Current Ratio & $\frac{\text { Current Assets }}{\text { Current Liabilities }}$ & $\begin{array}{l}\text { Published Financial } \\
\text { Statements }\end{array}$ \\
\hline $\boldsymbol{R O A}$ & Return on Assets & $\frac{\text { Net Profit After Tax }}{\text { Total Assets }} \times \frac{100}{1}$ & $\begin{array}{l}\text { Published Financial } \\
\text { Statements }\end{array}$ \\
\hline $\boldsymbol{D 2 E \boldsymbol { R }}$ & Debt to Equity ratio & $\frac{\text { Total liabilities }}{\text { Total equity }} \times \frac{100}{1}$ & $\begin{array}{l}\text { Published Financial } \\
\text { Statements }\end{array}$ \\
\hline
\end{tabular}

Source: Dabor (2008) and Researcher's Computation (2016)

\subsection{Method of Data Analysis}

The Wilcoxon signed-rank test for two related samples is used to test the hypothesis of interest. The Wilcoxon signed-rank tests are non-parametric tests which are suited for studies with small samples (Jerome, 2008).

The Wilcoxon signed-rank test is carried out to ascertain whether significant differences exist in the profitability, liquidity and financial leverage of banks using IFRS and SAS based financial statements. The test is carried out at three levels; the first involves an investigation into the general difference in ROA of the selected banks; the second level is concerned with the difference in Current ratio of the selected banks while the third phase is concerned with the difference in Debt to Equity of the selected banks before and after the adoption of IFRS. All these three phases would be considered for the year under investigation. In order to carry out these tests, the firm performance proxies are calculated for every bank in 2011 financial 


\section{Macrothink}

International Journal of Accounting and Financial Reporting

ISSN 2162-3082 2018, Vol. 8, No. 3

year. The advantage with Wilcoxon signed-rank test is that it neither depends on the form of the parent distribution nor on its parameters neither does it require any assumptions about the shape of the distribution. For this reason, this test is often used as an alternative to t-test whenever the population cannot be assumed to be normally distributed. Even if the normality assumption holds, it has been shown that the efficiency of this test compared to t-test is almost $95 \%$.

\section{Data Presentations, Results and Discussion}

\subsection{Data Presentation}

Data for IFRS adoption and firm profitability, liquidity and financial leverage were obtained from the secondary sources and converted to percentages and ratios respectively as presented in the tables below with an accompanying bar chart:

Table 2. IFRS adoption and firm profitability

\begin{tabular}{llll}
\hline & \multicolumn{2}{c}{ Financial Performance - Profitability (ROA) } \\
\cline { 2 - 4 } Bank & & Before IFRS Adoption & After IFRS Adoption \\
\hline Diamond & 1 & -1.40 & -1.72 \\
Ecobank & 2 & -207.89 & 1782.76 \\
Fidelity & 3 & 0.94 & 0.35 \\
First Bank & 4 & 1926.57 & 932.74 \\
FCMB & 5 & -1.92 & -1.83 \\
Skyebank & 6 & 0.74 & 0.30 \\
Standard & 7 & 3.17 & 3.93 \\
Stanbic & 8 & 0.75 & 0.60 \\
UBA & 9 & 989.75 & 478.14 \\
Unity & 10 & 0.66 & 0.75 \\
Wema & 11 & -3.65 & -1.91
\end{tabular}

Source: Researcher's Computation (2016)

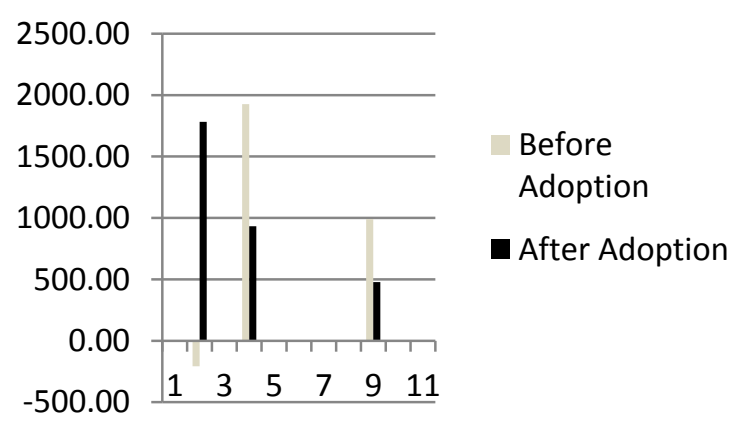

Figure 1. IFRS adoption on firm profitability

Table 2 above shows the results of the computed ratio for financial performance measure of profitability as proxied by return on total assets (ROA) for the selected banks before the 


\section{Macrothink}

International Journal of Accounting and Financial Reporting

ISSN 2162-3082 2018, Vol. 8, No. 3

adoption of the IFRS (that is, for final accounts of the banks prepared using the Nigerian SAS) for a single year (2011) and the ratios after the adoption of IFRS (that is, for final accounts of the banks prepared using the IFRS) for the same year. Figure 1 shows a pictorial representation of both variables. From the table and chart, Ecobank seemed to have performed negatively before the IFRS adoption (-207.89) but dramatically improved after the IFRS adoption (782.76). First bank and Union bank appeared to have a better performance before the adoption (1926.57 and 989.75 respectively) but performance dropped after the adoption (932.74 and 478.14 respectively). The impacts on other banks were not very significant.

Table 3. IFRS adoption and firm liquidity

Financial Performance - Liquidity (CUR)

\begin{tabular}{llll} 
Bank & & Before IFRS Adoption & After IFRS Adoption \\
\hline Diamond & 1 & 1.08 & 1.06 \\
Ecobank & 2 & 1.00 & 1.01 \\
Fidelity & 3 & 1.23 & 1.25 \\
First Bank & 4 & 1.15 & 1.15 \\
FCMB & 5 & 1.19 & 1.19 \\
Skyebsnk & 6 & 1.14 & 1.13 \\
Standard & 7 & 1.15 & 1.18 \\
Stanbic & 8 & 1.15 & 1.15 \\
UBA & 9 & 1.08 & 1.09 \\
Unity & 10 & 1.01 & 1.01 \\
Wema & 11 & 0.97 & 0.96
\end{tabular}

Source: Researcher's Computation (2016)

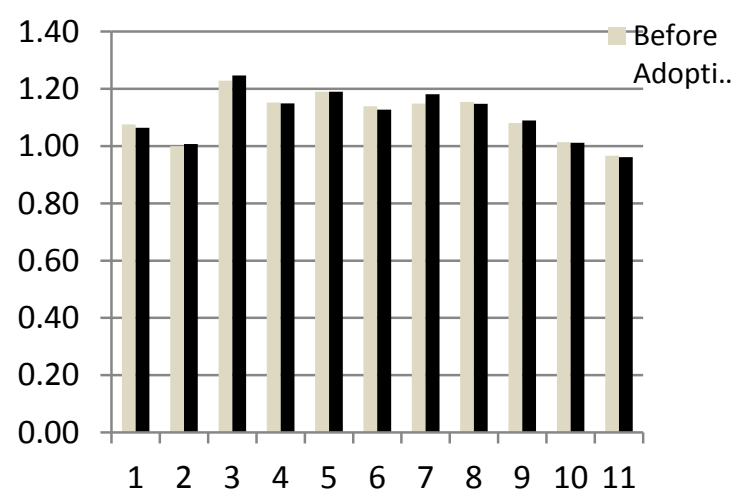

Figure 2. IFRS adoption and firm liquidity

Table 3 above shows the results of the computed ratio for financial performance measure of the liquidity as proxied by the current ratio (CUR) for the selected banks before adoption of the IFRS for a single year (2011) and the ratios after adoption of IFRS for the same year. 


\section{Mll Macrothink}

International Journal of Accounting and Financial Reporting

ISSN 2162-3082

2018, Vol. 8, No. 3

Figure 2 shows a pictorial representation of both computed ratios. From the chart, Diamond bank, Skye bank and Wema bank appeared to have performed better before the adoption (1.08, 1.14 and 0.97 respectively) than after the adoption of the IFRS (1.06, 1.13 and 0.96 respectively). Ecobank, Fidelity bank, Standard Chartered bank and UBA appeared to have performed better after the adoption (1.01, 1.25, 1.18 and 1.09 respectively) than before the adoption (1.00, 1.23, 1.15 and 1.08 respectively). First bank, FCMB, Stanbic IBTC and Unity bank Appeared not to have been significantly impacted on the ratios computed for both periods were consistent. On the whole, Wema bank appeared to have the least liquidity while fidelity bank appeared to have the highest liquidity ratio for both periods under review.

Table 4. IFRS adoption and firm financial leverage

\section{Financial Performance - Financial Leverage (D/ER)}

\begin{tabular}{llll}
\cline { 2 - 4 } Bank & & Before IFRS Adoption & After IFRS Adoption \\
\hline Diamond & 1 & 7.62 & 8.28 \\
Ecobank & 2 & 0.02 & 0.01 \\
Fidelity & 3 & 4.37 & 4.05 \\
First Bank & 4 & 0.01 & 0.01 \\
FCMB & 5 & 4.11 & 4.12 \\
Skyebank & 6 & 7.18 & 7.83 \\
Standard & 7 & 5.49 & 4.64 \\
Stanbic & 8 & 6.47 & 6.76 \\
UBA & 9 & 0.01 & 0.01 \\
Unity & 10 & 7.33 & 7.51 \\
Wema & 11 & 32.07 & 34.28
\end{tabular}

Source: Researcher's Computation (2016)

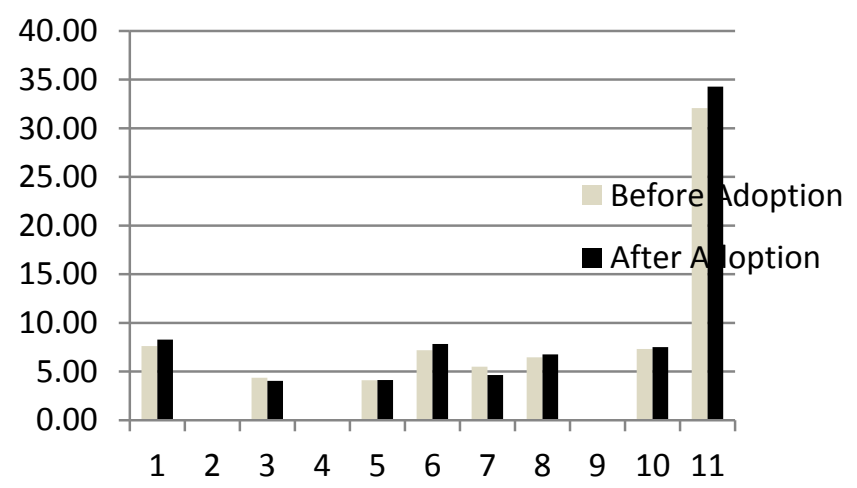

Figure 3. IFRS adoption on firm financial leverage

Table 4 above shows the results of the computed ratio for financial performance proxy of firm financial leverage as measured by the debt to equity ratio (D/ER) for the selected banks before adoption of the IFRS and the ratios after adoption of the IFRS for the year. Figure 3 shows a pictorial representation of both computed ratios. From the chart, Diamond bank, FCMB, Skyebank Stanbic IBTC and Wema bank appeared to have a lower leverage ratio 


\section{Ml Macrothink}

International Journal of Accounting and Financial Reporting

ISSN 2162-3082

2018, Vol. 8, No. 3

before the adoption $(7.62,4.11,7.18,7.33$ and 32.07 respectively) than after adoption of the IFRS (8.28, 4.12, 7.83, 6.76, 7.51 and 34.28 respectively). Ecobank, Fidelity bank and Standard Chartered bank appeared to have a higher leverage ratio before the adoption $(0.02$, 4.37 and 5.49 respectively) but a lower leverage ratio after the adoption of IFRS (0.01, 4.05 and 4.64 respectively). First bank and UBA appear not to have been significantly impacted as the ratios computed for both periods were consistent. On the whole, Wema bank appeared to have the highest computed leverage ratio while First bank and Unity bank appeared to have the least computed leverage ratio for both periods under review.

\subsection{Wilcoxon Signed-Rank Test}

Below is the result of the Wilcoxon signed-rank test, a non-parametric test employed to analyse the difference between the ratios for the selected banks before adoption of IFRS and the ratios for the same banks after adoption of IFRS. The results (Appendixes 3 to 5) are as presented:

Table 5. The Wilcoxon Signed-Rank Test for IFRS adoption on firm profitability, liquidity and financial leverage

\begin{tabular}{|c|c|c|c|}
\hline & $\begin{array}{l}\text { Financial } \\
\text { Performance } \\
\text { Profitability (ROA) }\end{array}$ & $\begin{array}{l}\text { Financial } \\
\text { Performance } \\
\text { Liquidity (Current } \\
\text { Ratio) }\end{array}$ & $\begin{array}{l}\text { Financial } \\
\text { Performance - } \\
\text { Financial } \\
\text { Leverage (D/ER) }\end{array}$ \\
\hline Effective Sample Size (n) & 11.00 & 8 & 8 \\
\hline Standard Deviation & 22.4900 & 14.2829 & 14.2829 \\
\hline Test Statistics & 0.3600 & -0.5601 & -0.8402 \\
\hline p-value (Lower Tail) & 0.6389 & 0.2877 & 0.2004 \\
\hline p-value (Upper Tail) & 0.3611 & 0.7123 & 0.7996 \\
\hline p-value (Two Tail) & 0.7221 & 0.5754 & 0.4008 \\
\hline$\propto$ & 0.05 & 0.05 & 0.05 \\
\hline T-Table value & 10 & 3 & 10 \\
\hline$\sum R_{+}$ & 37 & 14 & 11 \\
\hline$\sum R_{-}$ & 29 & 22 & 25 \\
\hline$\sum_{R_{\mp}}$ & 8 & -8 & -12 \\
\hline
\end{tabular}

Source: Researcher's Computation (2016) 


$$
\begin{gathered}
\sum R_{+}=\text {Sum of Positive Rank, } \\
\sum R_{-}=\text {Sum of Negative Rank, } \\
\sum R_{\overline{+}}=\text { Sum of signed Rank, } \\
\propto=\text { Level of significance }
\end{gathered}
$$

\subsection{Test of Hypotheses}

The following hypotheses were tested:

\subsubsection{Hypothesis One}

$\mathbf{H}_{1}$ : IFRS adoption does not significantly affect profitability of Nigerian banks.

Profitability ratios were tested for difference in variances. Return on assets ratio P-value of 0.7221 is greater than $\boldsymbol{\alpha}=0.05$ which prescribes failure to accept or reject the null hypotheses. The variation of IFRS profitability ratios is not equal to the variation of SAS based profitability ratios There is a significant difference in the dispersion of the IFRS profitability and the Nigerian SAS based profitability ratios. Table 4.4 above, taking the smaller value of the calculated $\mathrm{T}, \mathrm{T}=29$, at $\boldsymbol{\alpha}=0.05$ level of significance, with $\mathrm{n}=11$, and the table value of $\mathrm{T}=10$, the comprehensive return on assets ratio from the calculated Wilcoxon signed-rank test of 29 is greater than the table value of 10 . We therefore conclude that there is a statistically significant difference in the dispersion of variations of the IFRS profitability ratios and the Nigerian SAS based profitability ratios. Furthermore, the standard deviation of +0.3600 and sum of signed rank of +8.00 suggests a positive impact of the adoption on profitability of Nigerian banks (see also appendix 3 ).

\subsubsection{Hypothesis Two}

$\mathbf{H}_{2}$ : IFRS adoption does not significantly affect liquidity of Nigerian banks.

Liquidity ratios were tested for difference in variances. Current ratio P-value of 0.5754 is greater than $\alpha=0.05$ which prescribes failure to accept the null. The variation of IFRS financial values of current ratio is not equal to the variation of SAS based financial values of current ratio. There is therefore a significant negative difference in the dispersion of the IFRS liquidity ratios and the Nigerian SAS based liquidity ratios. From table 4.4 above, the smaller value of the calculated T, $\boldsymbol{T}=14$, at $\boldsymbol{\alpha}=0.05$ level of significance, with $\boldsymbol{n}=8$, and the table value of $\boldsymbol{T}=3$. This shows that the comprehensive current ratio from the calculated Wilcoxon signed-rank test of $\mathbf{1 4}$ is greater than the table value of $\mathbf{3}$. We therefore conclude that there is a statistically significant difference in the dispersion of variations of the IFRS current ratios and the Nigerian SAS current ratios. Furthermore, the standard deviation of -0.5601 and sum of signed rank of -8.00 portrays a negative impact of the adoption on liquidity of Nigerian banks. (See also appendix 4) 


\subsubsection{Hypothesis Three}

$\mathbf{H}_{3}$ : IFRS adoption does not significantly affect the leverage of Nigerian banks.

Financial leverage ratios were also tested for difference in variances. The debt to equity ratio P-value of 0.4008 is greater than $\alpha$ of 0.05 , which suggests rejection of the null hypothesis. The variation of IFRS financial values of debt to equity ratio is therefore not equal to the variation of Nigerian SAS based values. Hence, there is a significant difference in the dispersion of the IFRS financial leverage ratios and the Nigerian SAS based leverage ratios. From table 4.4 above, the smaller value of the calculated T, $\boldsymbol{T}=11$, at $\boldsymbol{\alpha}=0.05$ level of significance, with $\boldsymbol{n}=8$, and the table value of $\boldsymbol{T}=10$. This shows that the comprehensive debt to equity ratio from the calculated Wilcoxon signed-rank test of $\mathbf{1 1}$ is greater than the table value of 10. We therefore conclude that there is a statistically significant difference in the dispersion of variations of the IFRS current ratios and the Nigerian SAS based leverage ratios. Moreover, a cursory look reveals that the standard deviation of -0.8402 and sum of signed rank of -12 portrays a negative impact of the adoption of IFRS on the leverage ratio of Nigerian banks (See also appendix 5).

\section{Summary of Findings, Conclusion and Recommendations}

\subsection{Summary of Findings}

We empirically evaluated the impact of IFRS adoption on the financial performance of selected Nigerian deposit money banks. The results are summarized below:

- IFRS adoption significantly and positively affects profitability of Nigerian banks

- IFRS adoption significantly but negatively affects liquidity of Nigerian banks

- IFRS adoption significantly but negatively affects financial leverage of Nigerian banks

\subsection{Conclusion}

The main purpose of this study is to examine the effect of International Financial Reporting Standards (IFRS) adoption on the financial performance of selected deposit money banks in Nigeria using some ratios selected from three major categories of financial ratios. Based on the findings of this study, we conclude that IFRS adoption by Nigerian deposit money banks has impacted significantly on their financial performance. Accounting standards serve an important role of communicating financial data between the entities and their financial statements users. They are designed to provide accurate and credible information for the decision makers in order to rely on it. Therefore, the accuracy and reliability of financial statements are very important. This research adds to the body of knowledge on IFRS adoption in Nigeria by indicating that conversion to IFRS Nigeria has statistically significant effects on the profitability, liquidity and leverage ratios of Nigerian deposit money banks.

\subsection{Recommendations}

In assessing the implications of IFRS adoption, the entire organization of each company facing or having faced this transition should be involved. The management team, employees, 
auditors, and advisors should be aware of the effect of IFRS on financial reporting and trend analysis. We therefore recommend that the management of banking firms and their financial statements preparers should be cautious in examining these impacts. Flowing from the increase in the volatility of ratios (used in this study), after the IFRS adoption, firms should prepare adequately on all fronts for the implementation of IFRS and anticipate such changes, though they may be a short-term fluctuation rather than a long-term trend. There should also be continuous enlightenment campaigns on the potential effects of IFRS implementation by the regulatory authorities, professional bodies and the government as more and more companies in Nigeria change from SAS based financial reporting to IFRS. Furthermore, companies should endeavor to use the opportunity presented by the adoption of IFRS to improve their business processes in all ramifications so as to aid uniformity and transparency.

\section{References}

Abdulkadir, M. (2012). Adoption of International Financial Reporting Standards in Developing Countries: The Case of Nigeria. International Journal of Business and Management, 7(3), 52-161.

Abrams, F. K. (1951). Management Responsibilities in a Complex World. Harvard Business Review, 39, 29-34.

Adam, M. (2009). Nigerian Banks: The Challenges of Adopting International Financial Reporting Standards. Zenith Economic Quarterly, 17-26.

Adeyemi, S. B., \& Olowookere, U. M. (2011). An Empirical Investigation of the Audit Expectation Gap in Nigeria. African Journal of Business Management, 5.

Akindele, O. A. (2012). Impacts of IFRS Adoption on Financial Statement. Unpublished B.Sc. Business Administration project, Vaasa University of Applied Sciences.

Alchian, A., \& Demsetz, H. (1972). Production, Information Costs, and Economic Organization. American Economic Review, 62, 777-795.

Anao, R. A. (2012). Financial Reporting Council (FRC) Act and Nigeria. Roadmap to IFRS implication for accounting education in Nigeria, a paper presented in Abuja: Financial Reporting Council of Nigeria.

Ball, R. (2006). International Financial Reporting Standards (IFRS): Pros and Cons for Investors. Accounting and Business Research, 36, 5-27.

Barth, M. E., Jagolizer, A. D., Armstrong, C. S., \& Riedl, E. J. (2008). Market Reaction to the Adoption of IFRS in Europe. Stanford University.

Barth, M. E. (2007). Research, Standard Setting, and Global Financial Reporting. Hanover. MA: New Publishers.

Blanchette, M., Racicot, F. E., \& Girard, J. Y. (2011). The Effects of IFRS on Financial Ratios: Early Evidence in Canada. Ottawa, Certified General Accountants Association of Canada.

Brüggemann, U., Hitz, J., \& Sellhorn, T. (2013). Intended and Unintended Consequences of 


\section{MlMacrothink}

International Journal of Accounting and Financial Reporting

ISSN 2162-3082

2018, Vol. 8, No. 3

Mandatory IFRS Adoption: A Review of Extant Evidence and Suggestions for Future Research. European Accounting Review, 22, 1-37.

Bushman, R., \& Smith, A. (2001). Financial Accounting Information and Corporate Governance. Journal of Accounting and Economics, 32, 237-334.

Caldwell, C., \& Karri, R. (2005). Organizational Governance and Ethical Choices: A Covenantal Approach to Building Trust. Journal of Business Ethics, 58(1), 249-259.

Choi, F. S., \& Mueller, G. G. (1984). International Accounting. Englewood Cliffs, New Jersey: Prentice- Hall, Inc.

Chua, W. F., \& Taylor, S. L. (2008). The Rise and Rise of IFRS: An Examination of IFRS Diffusion. Journal of Accounting \& Public Policy, 27(6), 462-473.

Covrig, V., Defond, M., \& Hung, M. (2007). Home Bias, Foreign Mutual Fund Holdings, and the Voluntary Adoption of International Accounting Standards. Journal of Accounting Research, 45, 41-70.

Cuijpers, R., \& Buijnik, W. (2005). Voluntary Adoption of Non -local GAAP in the European Union: A Study of Determinants and Consequences. European Accounting Review, 14(3), 487-524.

Daske, H., \& Gebhardt, G. (2006). International Financial Reporting Standards and Experts' perceptions of disclosure quality. Abacus, 42(3-4), 461-498.

Daske, H., Hail, L., Leuz, C., \& Verdi, R. (2008). Mandatory IFRS Reporting Around the World: Early Evidence on the Economic Consequences. Journal of Accounting Research, 46(5), 1085-1142.

Davis J., Schoorman, F., \& Donaldson, L. (1997). Toward a Stewardship Theory of Management. Academy of Management Review, 22(1), 20-47.

Diamond, D. W., \& Verrecchia, R. E. (1991). Disclosure, Liquidity, and the Cost of Capital. The Journal of Finance, 46(4), 1325-1359.

Donaldson, L., \& Davis, J. H. (1989). CEO Governance and Shareholder Returns: Agency Theory or Stewardship Theory. Annual Meeting of the Academy of Management, 49-63. Washington.

Donaldson, L., \& Davis, J. H. (1991). Stewardship Theory or Agency Theory: CEO Governance and Shareholder Returns. Australian Journal of Management, 16(1), 49-64.

Epstein, B. J. (2009). The Economic Effects of IFRS adoption. The CPA Journal, 26-30.

Fama, E. (1980). Agency Problems and the Theory of the Firm. Journal of Political Economy, 288-307.

Freeman, E. (1984). Strategic Management: A Stakeholder Approach. Boston, Pitman Press. Freeman, R. E. (2004). A Stakeholder Theory of Modern Corporations. Journal of Ethical 
Theory and Business, 56-65.

Garuba, A. O., \& Donwa, P. (2012). The Challenges of Adopting International Financial Reporting System in Nigeria. JORINDI, 9, 313-317.

Gebhardt, G., \& Novotny-Farkas, Z. (2010). The Effects of IFRS Adoption on the Financial Reporting Quality of European Banks, Marie Curie Research Training Network. The IFRS Revolution: Compliance, Consequences and Policy Lessons.

Gray R., Owen D., \& Adams C. (1996). Accounting and Accountability: Changes and Challenges in Corporate Social and Environment Reporting. London: Prentice Hall.

Healy, P. M., \& Palepu, K. G. (2001). Information Asymmetry, Corporate Disclosure, and the Capital Markets: A Review of the Empirical Disclosure Literature. Journal of Accounting and Economics, 31, 405-440.

Herbert, W. E. (2010). Adoption of IFRS in Nigeria: Assessing the Level of Preparedness. A Paper Presented at FSS2020 Retreat on IFRS. Central Bank of Nigeria (CBN), Abuja.

Herbert, W. E., \& Tsegba, I. N. (2013). Economic Consequences of International Financial Reporting Standards (IFRS) Adoption: Evidence from a Developing Country. European Journal of Business and Management, 5(28).

Holt, G. J., \& Mirza, A. A. (2011). Wiley IFRS: Practical Implementation Guide and Workbook. Hoboken, N. J.

Ibiamke, N. A., \& Ateboh-Briggs, P. B. (2014). Financial Ratios Effects of International Financial Reporting Standards (IFRS) Adoption in Nigeria. Journal of Business and Management Invention, 3(3), 50-59.

Institute of Chartered Accountants of Nigeria. (2006). Financial Reporting and Audit Practice. Lagos: VI Publishing Ltd.

International Accounting Standards Board. (2003). International Financial Reporting Standards Including International Accounting Standards and Interpretations. London.

International Accounting Standards Board. (2010). The Conceptual Framework for Financial Reporting. London.

International Federation of Accountants. (2008). Global Survey Recognizes Profession's Role in Contributing to Economic Growth and Highlights Need for More Accounting Talent. Retrieved 11 February, 2016, from http://www.ifac.org/globalsurvey

Iyoha, F. O., \& Faboyede, S. O. (2011). Adopting International Financial Reporting Standards (IFRS) - A Focus on Nigeria. International Journal of Research in Commerce and Management, 2(1), 35-40.

Jensen, M. C., \& Meckling, W. H. (1976). Theory of the Firm: Managerial Behaviour, Agency Costs and Ownership Structure. Journal of Financial Economics, 3, 305-360.

Kiel, G., \& Nicholson, G. (2003). Board Composition and Corporate Performance: How the 


\section{$\triangle 1$ Macrothink}

International Journal of Accounting and Financial Reporting ISSN 2162-3082 2018, Vol. 8, No. 3

Australian Experience Informs Contrasting Theories of Corporate Governance. Corporate Governance: An International Review, 11(3), 189-205.

\section{Appendixes}

Appendix 1. Computed ratios before adoption of IFRS

\begin{tabular}{|c|c|c|c|c|}
\hline S/No. & Banks & Return On Assets & Current Ratio & Debt/Equity Ratio \\
\hline 1 & Diamond & -1.40 & 1.08 & 7.62 \\
\hline 2 & Ecobank & -207.89 & 1.00 & 0.02 \\
\hline 3 & Fidelity & 0.94 & 1.23 & 4.37 \\
\hline 4 & First Bank & $1,926.57$ & 1.15 & 0.01 \\
\hline 5 & FCMB & -1.92 & 1.19 & 4.11 \\
\hline 6 & Skye & 0.74 & 1.14 & 7.18 \\
\hline 7 & Standard & 3.17 & 1.15 & 5.49 \\
\hline 8 & Stanbic & 0.75 & 1.15 & 6.47 \\
\hline 9 & UBA & 989.75 & 1.08 & 0.01 \\
\hline 10 & Unity & 0.66 & 1.01 & 7.33 \\
\hline 11 & Wema & -3.65 & 0.97 & 32.07 \\
\hline
\end{tabular}

Appendix 2. Computed ratios after the IFRS

\begin{tabular}{lllll}
\hline S/No. & Banks & Return On Assets & Current Ratio & Debt/Equity Ratio \\
\hline 1 & Diamond & -1.72 & 1.06 & 8.28 \\
\hline 2 & Eco-bank & 1782.76 & 1.01 & 0.01 \\
\hline 3 & Fidelity & 0.35 & 1.25 & 4.05 \\
\hline 4 & First Bank & 932.74 & 1.15 & 0.01 \\
\hline
\end{tabular}




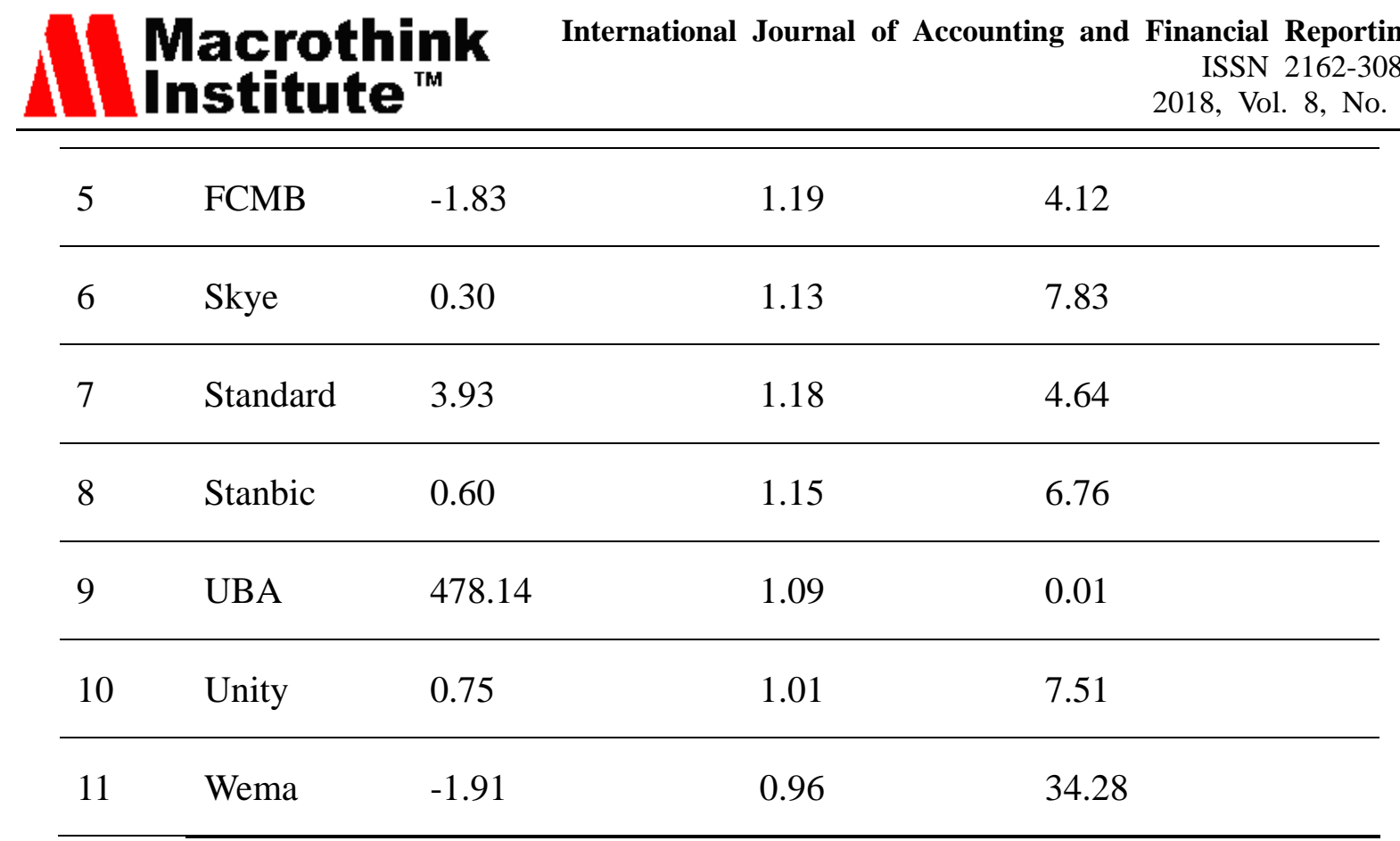

Appendix 3. The Wilcoxon signed-rank test for IFRS adoption on firms profitability

Financial Performance - Profitability (ROA)

\begin{tabular}{|c|c|c|c|c|c|c|c|}
\hline Banks & & $\begin{array}{l}\text { Before } \\
\text { Adoption }\end{array}$ & $\begin{array}{l}\text { After } \\
\text { Adoption }\end{array}$ & $\begin{array}{l}\text { Sign of } \\
\text { Difference }\end{array}$ & $\begin{array}{l}\text { Size of } \\
\text { Difference }\end{array}$ & $\begin{array}{l}\text { Rank of } \\
\text { Difference }\end{array}$ & $\begin{array}{l}\text { Signed } \\
\text { Rank }\end{array}$ \\
\hline Diamond & 1 & -1.40 & -1.72 & + & 0.3224 & 4 & 4 \\
\hline Ecobank & 2 & -207.89 & 1782.76 & - & 1574.8722 & 11 & -11 \\
\hline Fidelity & 3 & 0.94 & 0.35 & + & 0.5934 & 6 & 6 \\
\hline First Bank & 4 & 1926.57 & 932.74 & + & 993.8385 & 10 & 10 \\
\hline FCMB & 5 & -1.92 & -1.83 & - & 0.0900 & 1.5 & -1.5 \\
\hline Skye & 6 & 0.74 & 0.30 & + & 0.4440 & 5 & 5 \\
\hline Standard & 7 & 3.17 & 3.93 & - & 0.7600 & 7 & -7 \\
\hline Stanbic & 8 & 0.75 & 0.60 & + & 0.1517 & 3 & 3 \\
\hline UBA & 9 & 989.75 & 478.14 & + & 511.6161 & 9 & 9 \\
\hline Unity & 10 & 0.66 & 0.75 & - & 0.0900 & 1.5 & -1.5 \\
\hline Wema & 11 & -3.65 & -1.91 & - & 1.7400 & 8 & -8 \\
\hline
\end{tabular}




$$
\begin{array}{ll}
\sum_{R_{+}} & =37 \\
\sum_{R_{-}} & =29 \\
\sum_{R_{\mp}} & =8
\end{array}
$$

Effective Sample Size 11.00

Standard Deviation $\quad 22.49$

Test Statistics

Source: Researcher's Computation (2016), using MS Excel 2010.

\section{Calculation for Sum of Differences}

$$
\begin{aligned}
& \sum R_{+}=4+6+10+5+3+9=37 \\
& \sum R_{-}=11+1.5+7+1.5+8=29
\end{aligned}
$$

Taking the smaller value of the calculated $\mathrm{T}, \mathrm{T}=29$. At the $p=$ 0.05 level of significance, with $n$ $=11$, the table value of $\mathrm{T}$ is 10 .

Appendix 4. The Wilcoxon signed-rank test for IFRS adoption on firms liquidity Appendix 4A. Financial performance - liquidity (CUR)

\begin{tabular}{llllll} 
Banks & \multicolumn{1}{l}{ Before Adoption } & After Adoption & Sign of Difference & Size of Difference \\
\hline Diamond & 1 & 1.08 & 1.06 & + & 0.01 \\
Ecobank & 2 & 1.00 & 1.01 & - & -0.01 \\
Fidelity & 3 & 1.23 & 1.25 & - & -0.02 \\
First Bank & 4 & 1.15 & 1.15 & + & 0.00 \\
FCMB & 5 & 1.19 & 1.19 & + & 0.00 \\
Skye & 6 & 1.14 & 1.13 & + & 0.01 \\
Standard & 7 & 1.15 & 1.18 & - & -0.03 \\
Stanbic & 8 & 1.15 & 1.15 & + & 0.01 \\
UBA & 9 & 1.08 & 1.09 & - & -0.01
\end{tabular}




$\begin{array}{llllll}\text { Unity } & 10 & 1.01 & 1.01 & + & 0.00 \\ \text { Wema } & 11 & 0.97 & 0.96 & + & 0.01\end{array}$

First Bank, FCMB and Unity Bank are dropped from the analysis as the difference score is zero, so the number of banks, $n$ will now be 8 as shown below:

Appendix 4B. Financial performance - liquidity (CUR)

\begin{tabular}{|c|c|c|c|c|c|c|c|}
\hline \multicolumn{2}{|l|}{ Banks } & \multirow{2}{*}{$\begin{array}{l}\text { Before } \\
\text { Adoption }\end{array}$} & \multirow{2}{*}{$\begin{array}{l}\text { After } \\
\text { Adoption }\end{array}$} & \multirow{2}{*}{$\begin{array}{l}\text { Sign of } \\
\text { Difference } \\
+\end{array}$} & \multirow{2}{*}{$\begin{array}{l}\begin{array}{l}\text { Size of } \\
\text { Difference }\end{array} \\
0.01\end{array}$} & \multirow{2}{*}{$\begin{array}{l}\begin{array}{l}\text { Rank of } \\
\text { Difference }\end{array} \\
3.5\end{array}$} & \multirow{2}{*}{$\begin{array}{l}\text { Signed } \\
\text { Rank }\end{array}$} \\
\hline Diamond & 1 & & & & & & \\
\hline Ecobank & 2 & 1.00 & 1.01 & - & -0.01 & 3.5 & -3.5 \\
\hline Fidelity & 3 & 1.23 & 1.25 & - & -0.02 & 7 & -7 \\
\hline Skye & 6 & 1.14 & 1.13 & + & 0.01 & 3.5 & 3.5 \\
\hline Standard & 7 & 1.15 & 1.18 & - & -0.03 & 8 & -8 \\
\hline Stanbic & 8 & 1.15 & 1.15 & + & 0.01 & 3.5 & 3.5 \\
\hline UBA & 9 & 1.08 & 1.09 & - & -0.01 & 3.5 & -3.5 \\
\hline \multirow[t]{4}{*}{ Wema } & 11 & 0.97 & 0.96 & + & 0.01 & 3.5 & 3.5 \\
\hline & & & & & $\sum R_{+}=$ & 14.00 & \\
\hline & & & & & $\sum R_{-}=$ & 22.00 & \\
\hline & & & & & $\sum R_{\mp}=$ & -8.00 & \\
\hline \multicolumn{2}{|c|}{ Effective Sample Size } & \multicolumn{3}{|l|}{8.00} & \multicolumn{2}{|c|}{ p-value (Lower Tail) } & 0.2877 \\
\hline \multicolumn{2}{|c|}{ Standard Deviation } & \multicolumn{2}{|l|}{14.28} & & \multicolumn{2}{|c|}{ p-value (Upper Tail) } & 0.7123 \\
\hline \multicolumn{2}{|c|}{ Test Statistics } & -0.56 & & & \multicolumn{2}{|c|}{ p-value (Two Tail) } & 0.5754 \\
\hline
\end{tabular}

Source: Researcher's Computation (2016), using MS Excel 2010. 


\section{Calculation for Sum of Differences}

$\sum R_{+}=3.5+3.5+3.5+3.5=14$

Taking the smaller value of the calculated $\mathrm{T}, \mathrm{T}=$

$\sum R_{-}=3.5+7+8+3.5=22$ 14. At the $p=0.05$ level of significance, with $n=$ 8 , the table value of $\mathrm{T}$ is 3 .

Appendix 5. The Wilcoxon signed-rank test for IFRS adoption on firms financial leverage Appendix 5A. Financial performance - financial leverage (D/ER)

\begin{tabular}{|c|c|c|c|c|c|}
\hline Banks & & Before Adoption & After Adoption & Sign of Difference & Size of Difference \\
\hline Diamond & 1 & 7.62 & 8.28 & - & -0.66 \\
\hline Ecobank & 2 & 0.02 & 0.01 & + & 0.00 \\
\hline Fidelity & 3 & 4.37 & 4.05 & + & 0.32 \\
\hline First Bank & 4 & 0.01 & 0.01 & + & 0.00 \\
\hline FCMB & 5 & 4.11 & 4.12 & - & -0.01 \\
\hline Skye & 6 & 7.18 & 7.83 & - & -0.64 \\
\hline Standard & 7 & 5.49 & 4.64 & + & 0.85 \\
\hline Stanbic & 8 & 6.47 & 6.76 & - & -0.29 \\
\hline UBA & 9 & 0.01 & 0.01 & + & 0.00 \\
\hline Unity & 10 & 7.33 & 7.51 & - & -0.18 \\
\hline Wema & 11 & 32.07 & 34.28 & - & -2.22 \\
\hline
\end{tabular}

Eco-bank, First Bank and UBA are dropped from the analysis as the difference score is zero, so the number of banks, $\mathrm{n}$ will now be 8 as shown below:

Appendix 5B. Financial performance - financial leverage (D/ER)

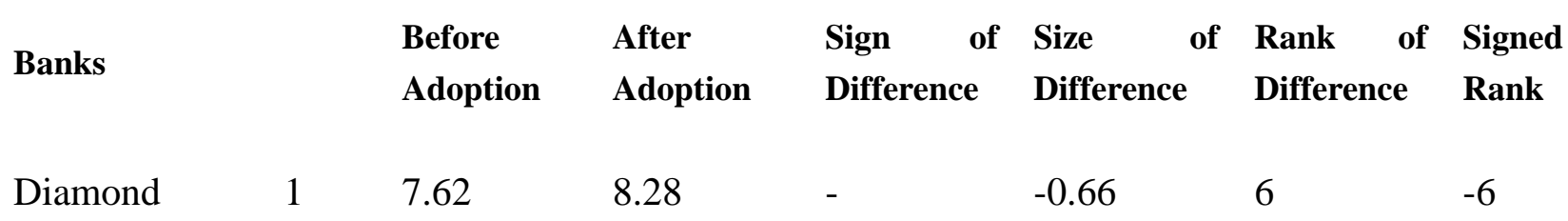




\begin{tabular}{|c|c|c|c|c|c|c|c|}
\hline Fidelity & 3 & 4.37 & 4.05 & + & 0.32 & 4 & 4 \\
\hline FCMB & 5 & 4.11 & 4.12 & - & -0.01 & 1 & -1 \\
\hline Skye & 6 & 7.18 & 7.83 & - & -0.64 & 5 & -5 \\
\hline Standard & 7 & 5.49 & 4.64 & + & 0.85 & 7 & 7 \\
\hline Stanbic & 8 & 6.47 & 6.76 & - & -0.29 & 3 & -3 \\
\hline Unity & 10 & 7.33 & 7.51 & - & -0.18 & 2 & -2 \\
\hline \multirow[t]{4}{*}{ Wema } & 11 & 32.07 & 34.28 & - & -2.22 & 8 & -8 \\
\hline & & & & & & 11.00 & \\
\hline & & & & & & 25.00 & \\
\hline & & & & & & -12 & \\
\hline \multicolumn{2}{|c|}{ Effective Sample Size } & \multicolumn{3}{|l|}{8.00} & \multicolumn{2}{|c|}{ p-value (Lower Tail) } & 0.2004 \\
\hline \multicolumn{2}{|c|}{ Standard Deviation } & \multicolumn{2}{|l|}{14.28} & & \multicolumn{2}{|c|}{ p-value (Upper Tail) } & 0.7996 \\
\hline \multicolumn{2}{|c|}{ Test Statistics } & -0.84 & & & \multicolumn{2}{|c|}{ p-value (Two Tail) } & 0.4008 \\
\hline
\end{tabular}

Source: Researcher's Computation (2016), using MS Excel 2010.

\section{Calculation for Sum of Differences}

$\sum R_{+}=4+7=11$

$\sum R_{-}=6+1+5+3+2+8=25$
Taking the smaller value of the calculated $\mathrm{T}, \mathrm{T}=11$. At the $p=0.05$ level of significance, with $n=8$, the table value of $\mathrm{T}$ is 10 . 
Appendix 6. Critical (table) values of the Wilcoxon T statistics

\begin{tabular}{|c|c|c|c|c|}
\hline \multirow[b]{2}{*}{$n$} & \multicolumn{2}{|c|}{0.05 Level of significance } & \multicolumn{2}{|c|}{0.01 Level of significance } \\
\hline & One-tailed test & Two-tailed test & One-tailed test & Two-tailed test \\
\hline 5 & 0 & - & - & - \\
\hline 6 & 2 & 0 & - & - \\
\hline 7 & 3 & 2 & 0 & - \\
\hline 8 & 5 & 3 & 1 & 0 \\
\hline 9 & 8 & 5 & 3 & 1 \\
\hline 10 & 10 & 8 & 5 & 3 \\
\hline 11 & 13 & 10 & 7 & 5 \\
\hline 12 & 17 & 13 & 9 & 7 \\
\hline 13 & 21 & 17 & 12 & 9 \\
\hline 14 & 25 & 21 & 15 & 12 \\
\hline 15 & 30 & 25 & 19 & 15 \\
\hline 16 & 35 & 29 & 23 & 19 \\
\hline 17 & 41 & 34 & 27 & 23 \\
\hline 18 & 47 & 40 & 32 & 27 \\
\hline 19 & 53 & 46 & 37 & 32 \\
\hline 20 & 60 & 52 & 43 & 37 \\
\hline 21 & 67 & 58 & 49 & 42 \\
\hline 22 & 75 & 65 & 55 & 48 \\
\hline 23 & 83 & 73 & 62 & 54 \\
\hline 24 & 91 & 81 & 69 & 61 \\
\hline 25 & 100 & 89 & 76 & 68 \\
\hline 26 & 110 & 98 & 84 & 75 \\
\hline 27 & 119 & 107 & 92 & 83 \\
\hline 28 & 130 & 116 & 101 & 91 \\
\hline 29 & 140 & 126 & 110 & 100 \\
\hline 30 & 151 & 137 & 120 & 109 \\
\hline 31 & 163 & 147 & 130 & 118 \\
\hline 32 & 175 & 159 & 140 & 128 \\
\hline 33 & 187 & 170 & 151 & 138 \\
\hline 34 & 200 & 182 & 162 & 148 \\
\hline 35 & 213 & 195 & 173 & 159 \\
\hline 36 & 227 & 208 & 185 & 171 \\
\hline 37 & 241 & 221 & 198 & 182 \\
\hline 38 & 256 & 235 & 211 & 194 \\
\hline 39 & 271 & 249 & 224 & 207 \\
\hline 40 & 286 & 264 & 238 & 220 \\
\hline 41 & 302 & 279 & 252 & 233 \\
\hline 42 & 319 & 294 & 266 & 247 \\
\hline 43 & 336 & 310 & 281 & 261 \\
\hline 44 & 353 & 327 & 296 & 276 \\
\hline 45 & 371 & 343 & 312 & 291 \\
\hline 46 & 389 & 361 & 328 & 307 \\
\hline 47 & 407 & 378 & 345 & 322 \\
\hline 48 & 426 & 396 & 362 & 339 \\
\hline 49 & 446 & 415 & 379 & 355 \\
\hline 50 & 466 & 434 & 397 & 373 \\
\hline
\end{tabular}

Source: Hinton, (2004)

\section{Copyright Disclaimer}

Copyright for this article is retained by the author(s), with first publication rights granted to the journal.

This is an open-access article distributed under the terms and conditions of the Creative Commons Attribution license (http://creativecommons.org/licenses/by/4.0/) 